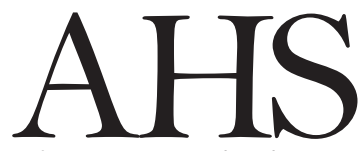

Advances in Horticultural Science

\title{
The induction and development of somatic embryos from the in vitro cul- tures of Catharanthus roseus (L.) G. Don
}

\author{
H. Farhadi ${ }^{1}$, M.B. Hassanpouraghdam ${ }^{1,2}$, M.A. Aazami ${ }^{1}(*)$ \\ 1 Department of Horticultural Sciences, Faculty of Agriculture, University \\ of Maragheh, Maragheh, Iran. \\ 2 Islamic Parliament Research Center, Tehran, Iran.
}

Key words: Catharanthus roseus (L.) G. Don, MS, PGR, somatic embryogenesis.

OPEN ACCESS

\footnotetext{
${ }^{(*)}$ Corresponding author:

Aazami58@gmail.com
}

\section{Citation:}

FARHADI H., HASSANPOURAGHDAM M.B., AAZAMI M.A., 2021 - The induction and development of somatic embryos from the in vitro cultures of Catharanthus roseus (L.) G. Don. - Adv. Hort. Sci.,35(1): 73-79

\section{Copyright:}

(C) 2021 Farhadi H., Hassanpouraghdam M.B. Aazami M.A. This is an open access, peer reviewed article published by Firenze University Press (http://www.fupress.net/index.php/ahs/) and distributed under the terms of the Creative Commons Attribution License, which permits unrestricted use, distribution, and reproduction in any medium, provided the original author and source are credited.

Data Availability Statement: All relevant data are within the paper and its Supporting Information files.

Competing Interests:

The authors declare no competing interests.

Received for publication 5 October 2020 Accepted for publication 1 February 2021
Abstract: Catharanthus roseus is containing anticancer alkaloids of vincristine and vinblastine and is an important medicinal plant. Several studies have conducted on in-vitro culture of this plant. To optimize the somatic embryogenesis, a factorial based on CRD experiment with 10 replications was conducted. Root, hypocotyl and leaf explants grown in-vitro were transferred and cultured on MS media containing different combinations of 2,4-D, NAA and 2,4-D×BAP. The results revealed that in callogenesis, the interaction effects of root and hypocotyl explants $\times 2,4-D$ and NAA as well as hypocotyl×(1 $\mathrm{mg} \mathrm{l}^{-1} \mathrm{NAA}+1 \mathrm{mg} \mathrm{l}^{-1}$ $B A P)$ was superior than other treatments $(p \leq 0.01)$. For calli fresh weight, hypocotyl×NAA and hypocotylx (1 $\left.\mathrm{mg} \mathrm{l}^{-1} \mathrm{NAA}+1 \mathrm{mg} \mathrm{l}^{-1} \mathrm{BAP}\right)$ was the treatment of choice $(p \leq 0.01)$. The calli produced were sub-cultured to attain the preembryos and somatic embryos. For the number of pre-embryos and somatic embryos; the interaction of hypocotyl×2,4-D was the most efficient treatment. Seemingly, the production of somatic embryos is accessible in this plant by the logical management of growth regulator combinations. Furthermore, the production and genetic engineering of the somatic embryos could be a promising trend in the subsequent production of high-valued metabolites from this plant.

\section{Introduction}

Catharanthus roseus (L.) G. Don, generally known as Madagascar Periwinkle, is a dicotyledonous plant with $2 n=16$ belongs to the family of Apocynaceae. Catharanthus roseus (L.) G. Don is an herbaceous plant that grows to a height of about $80 \mathrm{~cm}$ and is native of Madagascar (Hogan, 2003). More than 130 types of alkaloids have been extracted from the vegetative parts and roots of this plant, which are used to treat several diseases (Aslam et al., 2009). The most important alkaloids extracted from the shoots of this plant are vincristine and vinblastine, with a welldefined anti-cancer properties (Mujib et al., 2012). The amount of these compounds in this plant is about $0.0005 \%$ of dry weight of the plant and their extraction is costly and time consuming (Barrales-Cureño et al., 2017). These problems have led the scientists to a new approaches of tis- 
sue culture studies in C. roseus L. (Van Der Heijden et al., 2004). The first study done on tissue culture of Catharanthus roseus (L.) G. Don was in 1977. Those, researchers were able to produce callus from the plant (Dhruva et al., 1977). The production of shoots from callus has been successfully done in Catharanthus roseus L. (Ramawat et al., 1987). Somatic embryogenesis is a process by which somatic cells differentiate into embryos, called somatic embryos, which are used as one of the practical in vitro techniques for plant micro-propagation (Von Arnold et al., 2002). The first studies on somatic embryogenesis in the Catharanthus roseus (L.) G. Don was done in 1994, which were succeeded in producing somatic embryos by the anther culture (Kim et al., 1994). Furthermore, by hypocotyl explant and $1 \mathrm{mgl}^{-1}$ of 2,4-D (2,4-Dichlorophenoxyacetic acid), somatic embryos were obtained (Aslam et al., 2004, 2006). Growth regulators (composition and concentration) and the plant genetic make-up play a role in the success of somatic embryos production. The phenomenon of genotype-dependent plant regeneration also exists in other plant species (Firoozabady and De Boer, 1993).

The physiological conditions, the explant growth stage and embryogenic tissue type affect the production of somatic embryos. The tissue that has the highest metabolism and the least differentiation rate may have the suitable embryogenesis potential (Mikula and Rybczynski, 2001). Auxins, especially 2,4-D, are among the most important plant growth regulators initiate the somatic embryogenesis (Choi et al., 1999; Martin, 2003; Gulzar et al., 2019). In medicinal herb Spermatozoa hispida L.; cytokinin, especially BAP (6Benzylaminopurine), induced frequent somatic embryos (Deepak et al., 2019). With medicinal herb, Coccinia abyssinica; 2,4-D and BAP combination helped to produce embryogenic callus, and BAP triggered the production of somatic embryos (Abate et al., 2019). L-glutamine and L-alanine amino acids have had the most positive effect on somatic embryogenesis process (Ji et al., 2011). Various sources of carbon; such as sucrose, fructose, and glucose, as energy sources and osmotic regulators; play an important role in the somatic embryogenesis initiation and frequency (Aslam et al., 2011). MS has been employed as the most common culture medium for most of the plants (Ji et al., 2011). Somatic embryogenesis, leading to the regeneration of intact plants, is an eminent step in the plant transformation. Successful and sustainable transformation requires that a single cell give rise to a whole intact plant. The Ideal transformation takes place through the direct somatic embryogenesisfrom the single cells to reach the intact plants (Aslam et al., 2007).

The aim of the present study was to investigate the different explant types and the diverse plant growth regulators effects to induce somatic embryos and to study of the traits related to the somatic embryogenesis potential in Catharanthus roseus (L.) G. Don.

\section{Materials and Methods}

In vitro seed germination and seedlings production

The present study was conducted in the Research Laboratory, Department of Horticultural Sciences, University of Maragheh, Iran. The seeds were acquired from Pakan Bazr Isfahan Company. The seeds were immersed in water for one day before planting in the dark, and the next day, they were first treated with ethyl alcohol (70\%) for one minute and then disinfected with $20 \%$ solution of sodium hypochlorite for 10 more minutes. Then, they were washed with sterile distilled water 5 times. The disinfected seeds were cultured in petri dishes containing $20 \mathrm{ml}$ of MS medium (Murashige and Skoog, 1962) without plant growth regulators. In each petri dish; 10 disinfected seeds were cultured at $25-28^{\circ} \mathrm{C}$. After emergence, the seedlings were transferred to the photoperiod conditions with 16 hours of light at $25^{\circ} \mathrm{C}$ and 8 hours of darkness at $20^{\circ} \mathrm{C}$. After about 10 days, the $2-4 \mathrm{~cm}$ in length seedlings were suitable to continue the experiment.

\section{Preparation of culture media}

The culture medium was MS basic medium. Sucrose at a concentration of $30 \mathrm{~g} \mathrm{I}^{-1}$ was used as a source of carbon. Then, MS culture medium salts were added. $\mathrm{pH}$ was set at 5.8. At the last stage, $6 \mathrm{gl}^{-1}$ of agar was added and placed in an autoclave at $121^{\circ} \mathrm{C}$ for $20 \mathrm{~min}$. Agar-free culture medium (liquid) was employed for the somatic embryos.

\section{Experimental design}

A factorial experiment based on completely randomized design (CRD) was planned with 10 replications.

Factor 1: Plant growth regulators, concentration of 1 $\mathrm{mgl}^{-1}$ 2,4-D, $2 \mathrm{mgl}^{-1}$ NAA (1-Naphthaleneacetic acid), 1 $\mathrm{mg}^{-1} \mathrm{NAA}+1 \mathrm{mg}^{-1} \mathrm{BAP}$

Factor 2: Explants (Root, hypocotyl and leaf). 
Sampling and culture of explants in different treatments

The explants; root, hypocotyl and leaves were excised from the $2-4 \mathrm{~cm}$ seedling grown in vitro. Hypocotyl explants were cut into a length of about 1 $\mathrm{cm}$ and, in order to obtain embryogenic callus; they were cultured in the MS medium supplemented with the same treatments as subcultures. For calli proliferation; 3 weeks after the first date of cultivation, the same plant growth regulator treatments were applied to the subcultures. One month after the first subculture; embryogenic calluses were sub-cultured in MS medium supplemented with concentrations of $0.5,1$, and $1.5 \mathrm{~m} \mathrm{~g} \mathrm{l}^{-1} \mathrm{BAP}$. Then, the resulting calli were transferred to MS medium supplemented with $7 \mathrm{~g} \mathrm{l}^{-1}$ of agar, $30 \mathrm{~g} \mathrm{l}^{-1}$ of sucrose, $1 \mathrm{mg} \mathrm{l}^{-1}$ glutamine and $3 \mathrm{~g} \mathrm{l}^{-1}$ of polyethylene glycol with 6 replications. At the all stages of cultures and subcultures; the samples were kept in a growth chamber for $16 \mathrm{~h}$ light at $25^{\circ} \mathrm{C}$ and $8 \mathrm{~h}$ dark at $20^{\circ} \mathrm{C}$.

\section{Data mining and statistical analysis}

The callus production percentage, the percentage of necrotic calli and callus weight were noted. After multiple sub-cultures and transfer to the embryogenesis culture medium, the number of pre-embryogenic mass formed were recorded. SAS was used to analyze the variance, and mean comparisons were done with Duncan's multiple range test at $5 \%$ probability.

\section{Results}

\section{Callus production}

Hypocotyls of in vitro germinated seeds were used as explant on MS medium supplementary with 2,4-D and NAA, which induced white to yellowish callus within 10 days of incubation. The embryogenic callus was white, granular, friable, fast growing within 3 weeks of culture. The number of explants that produced callus and the necrotic calli proportion showed the callogenesis percentage and the percentage of necrotic calli (Fig. 1).

The mean comparison showed that for the callus formation, the interaction between root and 2,4-D; hypocotyl and 2,4-D; root and NAA; hypocotyl and $\mathrm{NAA}$; and hypocotyl and $1 \mathrm{mgl}^{-1} \mathrm{NAA}+1 \mathrm{mgl}^{-1} \mathrm{BAP}$ were significant at $1 \%$ probability level. Figure 2 shows the significant effect of auxin use on the rate of callus production. In this study 2,4-D was very efficient in producing callus and embryos on Catharanthus roseus. Embryonic callus was not observed using leaf explants and hypocotyl explants had the highest embryonic callus.

Furthermore, for the callus fresh weight, the interactions of hypocotyl and NAA; and hypocotyl $\times 1$ $\mathrm{mg} \mathrm{l}^{-1} \mathrm{NAA}+1 \mathrm{mgl}^{-1}$ BAP were significantly different from other treatments ( $p \leq 0.01$ ) (Fig. 3 ).

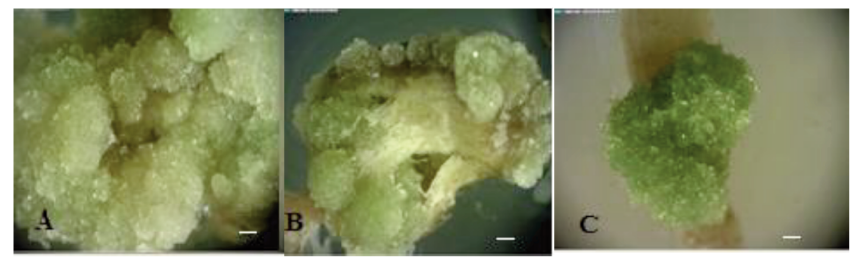

Fig. 1 - The effect of 2,4-D, NAA and BAP on hypocotyl explants of Catharanthus roseus and the formation of embryogenic callus ( 3 week after culture). Scale bars $=1.0 \mathrm{~mm}$. (A) Embryogenic callus from the treatment with $1 \mathrm{mg} \mathrm{l}^{-1} 2,4-$ D; (B) Embryogenic callus from the treatment with $2 \mathrm{mg} \mathrm{l}^{-}$ ${ }^{1} \mathrm{NAA},(\mathrm{C})$ Embryogenic callus from the treatment with 1 $\left.m g\right|^{1}-\mathrm{NAA}+1 \mathrm{mg} \mathrm{l}^{-1}$ BAP.

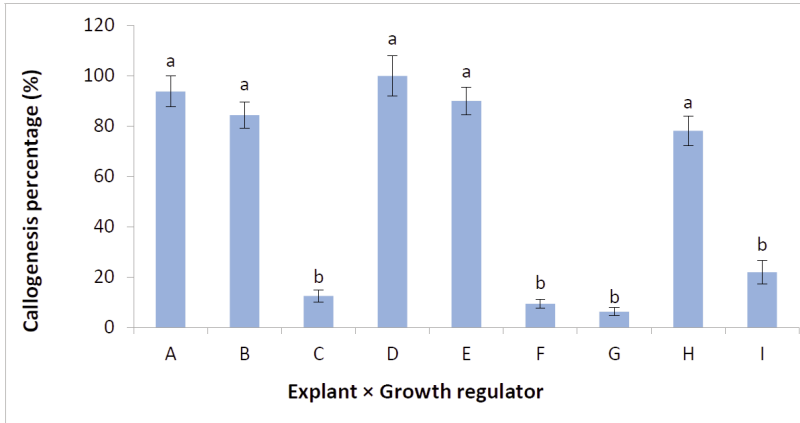

Fig. 2 - The interaction effects of explantxplant growth regulators on the callogenesis percentage of Catharanthus roseus. $\mathrm{A}=1 \mathrm{mg} \mathrm{l}^{-1}$ 2,4-Dxroot; $\mathrm{B}=1 \mathrm{mg} \mathrm{l}^{-1}$ 2,4-Dxhypocotyl; $C=1 \mathrm{mg} \mathrm{l}^{-1}$ 2,4-Dxleaf; $\mathrm{D}=2 \mathrm{mg} \mathrm{l}^{-1}$ NAA $\times$ root; $\mathrm{E}=2$ $\mathrm{mg} \mathrm{l}^{-1}$ NAAxhypocotyl; $\mathrm{F}=2 \mathrm{mg} \mathrm{l}^{-1} \mathrm{NAA} \times$ leaf; $\mathrm{G}=1 \mathrm{mg} \mathrm{l}^{-1}$ $\mathrm{NAA}+1 \mathrm{mg} \mathrm{l}^{-1} \mathrm{BAP} \times$ root, $\mathrm{H}=1 \mathrm{mg} \mathrm{l}^{-1} \mathrm{NAA}+1 \mathrm{mg} \mathrm{l}^{-1}$ BAP xhypocotyl; I= $1 \mathrm{mg} \mathrm{l}^{-1} \mathrm{NAA}+1 \mathrm{mg} \mathrm{l}^{-1} \mathrm{BAP} \times$ leaf).
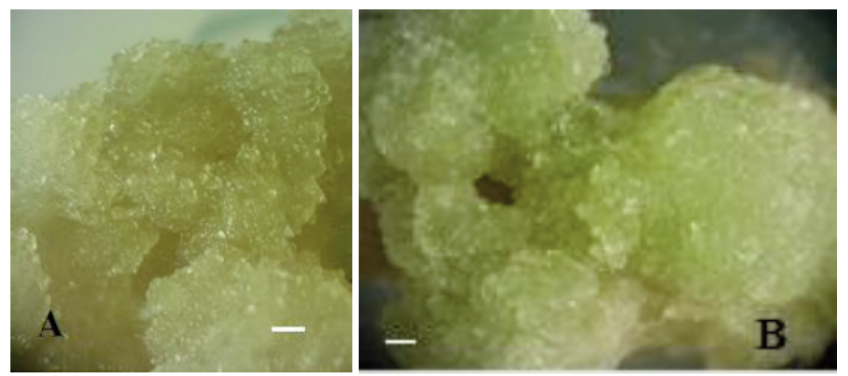

Fig. 3 - The effect of sub-culture of embryogenic calli from Catharanthus roseus hypocotyl influenced by different treatments (calli are produced 1 month after subculture). Scale bars $=1.0 \mathrm{~mm}$. (A) Embryogenic calli produced by the treatment of $2 \mathrm{mg} \mathrm{l}^{-1} \mathrm{NAA}$; (B) Embryogenic calli produced by the treatment of $\left(1 \mathrm{mgl}^{-1} \mathrm{NAA}+1 \mathrm{mg} \mathrm{l}^{-1} \mathrm{BAP}\right)$. 
The calli weight was obtained by weighting 10 samples. The results showed that the growth regulators and explants type and their interaction were significant on the weight of callus production, Treatment composition $\mathrm{H}$ and $\mathrm{E}$ with 0.85 and $0.81 \mathrm{~g}$, had the most callus weight respectively. The interaction of hypocotyl and NAA; and hypocotyl $x$ NAA + BAP were significant $(p \leq 0.01)$ on callus fresh weight (Fig. 4).

\section{Pre-embryonic and somatic embryogenic tissues}

In this study, two different approaches were employed to increase the formation of embryogenic calluses. Both approaches were aimed at choosing the best combination and concentration of plant growth regulators. Different masses were observed on the embryogenic calli tissues and the pre-embryonic structures were formed evidently. The number of masess of possible pre- and somatic embryos formed were counted. Somatic embryos were isolated by liquied culture and shown with distinct roots and shoots (Fig. 5).

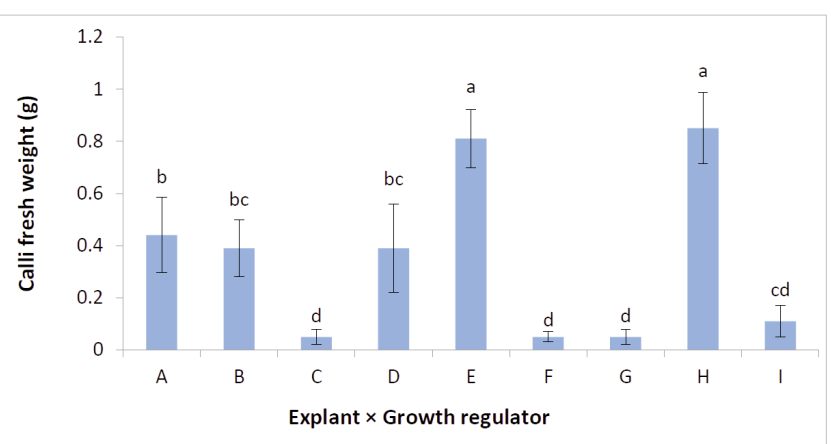

Fig. 4 - The interaction of explantxgrowth regulators on calli fresh weight at the in-vitro cultures of Catharanthus roseus. $A=1 \mathrm{mg} \mathrm{l}^{-1} 2,4-D \times$ root; $B=1 \mathrm{mg} \mathrm{l}^{-1}$ 2,4Dxhypocotyl; $\mathrm{C}=1 \mathrm{mg} \mathrm{l}^{-1}$ 2,4-Dxleaf; $\mathrm{D}=2 \mathrm{mg} \mathrm{l}^{-1} \mathrm{NAA} \times$ root; $\mathrm{E}=2$ $\mathrm{mg} \mathrm{l}^{-1}$ NAAxhypocotyl; $\mathrm{F}=2 \mathrm{mg} \mathrm{l}^{-1} \mathrm{NAA} \times$ leaf; $\mathrm{G}=1 \mathrm{mg} \mathrm{l}^{-1}$ $\mathrm{NAA}+1 \mathrm{mg} \mathrm{l}^{-1} \mathrm{BAP} \times$ root; $\mathrm{H}=1 \mathrm{mg} \mathrm{l}^{-1} \mathrm{NAA}+1 \mathrm{mg} \mathrm{l}^{-1}$ BAP xhypocotyl; I= $1 \mathrm{mg} \mathrm{l}^{-1} \mathrm{NAA}+1 \mathrm{mg} \mathrm{l}^{-1}$ BAPxleaf.

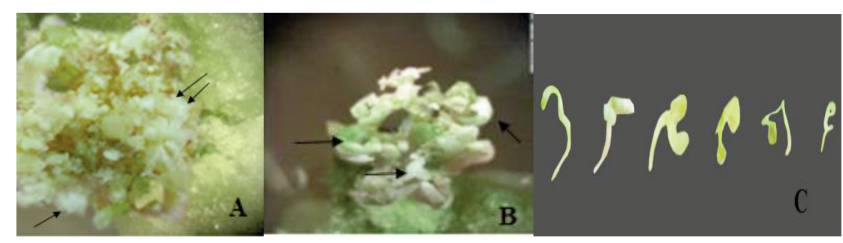

Fig. 5 - (A) Pre-embryo spots (bar= $1 \mathrm{~mm}$ ); (B) somatic embryos formed on the calli derived from hypocotyl explants of Catharanthus roseus (bar $=1 \mathrm{~mm}$ ); (C) Somatic embryos isolated from liquid cultures including root and shoot ends (bar= $5 \mathrm{~mm}$ ).
The results showed that the effect of plant growth regulators and explants, and their interactions were significant $(p \leq 0.01)$ on the number of pre-embryos and somatic embryos produced.

Furthermore, the interactions of hypocotyl $\times 2,4$ $D$ produced the highest number of pre-embryogenic and somatic embryogenic with mean 3.83 and 5.33 respectively in solid culture medium (Fig. 6).

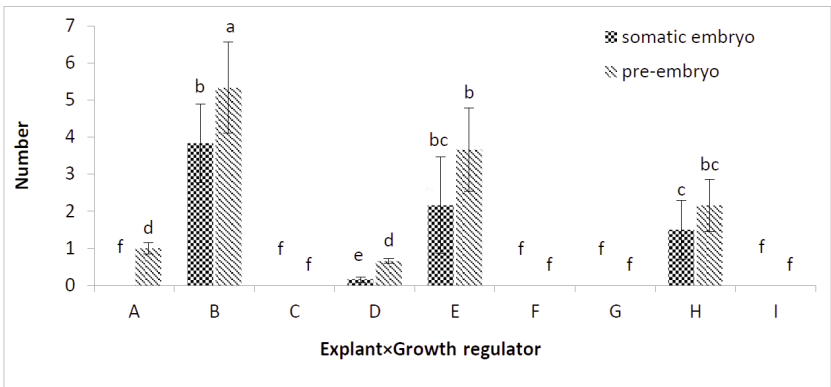

Fig. 6 - The interaction of explantxgrowth regulators on preembryos and somatic embryos number produced in Catharanthus roseus in-vitro culture. $A=1 \mathrm{mg} \mathrm{l}^{-1} 2,4-D \times$ root; $B=1 \mathrm{mg} \mathrm{l}^{-1} 2,4 \mathrm{D} \times$ hypocotyl; $\mathrm{C}=1 \mathrm{mg} \mathrm{l}^{-1} 2,4-\mathrm{D} \times$ leaf; $\mathrm{D}=2 \mathrm{mg} \mathrm{l}^{-1} \mathrm{NAA} \times$ root; $\mathrm{E}=2 \mathrm{mg} \mathrm{l}^{-1} \mathrm{NAA} \times$ hypocotyl; $\mathrm{F}=2$ $\mathrm{mg} \mathrm{l}^{-1} \mathrm{NAA} \times$ leaf; $\mathrm{G}=1 \mathrm{mg} \mathrm{l}^{-1} \mathrm{NAA}+1 \mathrm{mg} \mathrm{l}^{-1} \mathrm{BAP} \times$ root; $\mathrm{H}=$ $1 \mathrm{mg} \mathrm{l}^{-1} \mathrm{NAA}+1 \mathrm{mg} \mathrm{l}^{-1} \mathrm{BAP} \times$ hypocotyl; l= $1 \mathrm{mg} \mathrm{l}^{-1} \mathrm{NAA}+$ $1 \mathrm{mg} \mathrm{l}^{-1}$ BAP $\times$ leaf.

\section{Discussion and Conclusions}

The most frequently used auxin in the studies on somatic embryogenesis is 2,4-D (Bhojwani and Razdan, 1996; Junaid et al., 2006; Jushee et al., 2007). The significant effects of $1 \mathrm{mgl}^{-1} 2,4-\mathrm{D}$ has been proven on callus formation and somatic embryogenesis on Catharanthus roseus and Aconitum heterophyllum (Giri et al., 1993; Aslam et al., 2004). This auxin stimulates cell division and plays an important role in the production of callus (Paramageetham et al., 2004). Auxins alone or in combination with cytokinins are used for somatic embryogenesis induction and initiation (Wojcikowska and Gaj, 2016; Tanida and Shiota, 2019). More often, the use of cytokinins alone induces the production of non-embryogenic callus (Martin, 2004). In dicotyledonous plants, cytokinins are usually added to the culture medium along with auxins for the promotion of callus production (George et al., 2008). In medicinal herb, Asparagus racemosus Willd with the embryonic explants cultured on MS- medium and supplemented with $1.5 \mathrm{mgl}^{-1} 2,4-\mathrm{D}+0.43 \mathrm{mgl}^{-1} \mathrm{kin} ; 74 \%$ 
non-embryogenic callus was obtained (Chaudhary and Dantu, 2019). BAP is the major cytokinin used in the studies related to the somatic embryogenesis (Jimenez and Thomas, 2005). Singh et al. (2011) obtained $92 \%$ of non-embryogenic callus in Catharanthus roseus (L.) G. Don in MS culture medium supplemented with $1 \mathrm{mg} \mathrm{l}^{-1} \mathrm{NAA}+1 \mathrm{mg} \mathrm{l}^{-1} \mathrm{BAP}$ with hypocotyl explants. Our results are consistent with the findings of Aslam et al. (2006) in which hypocotyl explants in MS medium supplemented with $1 \mathrm{mgl}^{-1} 2,4-\mathrm{D}$, resulted in $85 \%$ of embryogenic callus. Moreover, they reached $73 \%$ of embryogenic callus by hypocotyl explant in the MS medium enriched with $1.5 \mathrm{mgl}^{-1} \mathrm{BAP}+1 \mathrm{mgl}^{-1} \mathrm{NAA}$; and $61.75 \%$ of embryogenic callus by hypocotyl explants in $\mathrm{MS}$ medium supplemented $1 \mathrm{mgl}^{-1} \mathrm{NAA}+1 \mathrm{mgl}^{-1}$ BAP as well as $85 \%$ of embryogenic callus by hypocotyl explant again in MS medium enriched with $1 \mathrm{mgl}^{-1}$ 2,4-D (Aslam et al., 2007). Studies have shown that $1 \mathrm{mgl}^{-1}$ 2.4-D in Ocimum basilicum L., produced about $75 \%$ of embryogenic calli (Gopi and Ponmurugan, 2006). Also, the results of another study revealed that by culturing hypocotyl explants in MS medium containing $1 \mathrm{mg} \mathrm{l}^{-1} \mathrm{NAA}+3 \mathrm{mgl}^{-1} \mathrm{BA} ; 80 \%$ of non-embryonic callus was observed (Ren et al., 2020).

Auxins and cytokinins form callus tissues by accelerating the division of plant cells (George et al., 2008). In Withania somnifera stems cultured in MS medium with $1 \mathrm{mgl}^{-1} \mathrm{BAP}+1 \mathrm{mgl}^{-1} \mathrm{NAA}$; calli were produced with an approximate weight of $0.22 \mathrm{~g}$ (Adhicari and Pant, 2013). In another study, internode explants of Centella asiatica L. on MS supplemented with auxins and cytokinins produced calli weighting up to $1.5 \mathrm{~g}$ (Martin, 2004).

2,4-D causes the rapid cell division and the polarization of cells (Jushee et al., 2007). Our results are almost similar with the findings of Choi et al. (1999) On Eleutherococcus senticosus ( $75 \%$ of somatic embryos). Moreover, the findings of the present study are in line with the results of Martin (2003) on Holostema adakodien, which by using different explants and plant growth regulators; they clearly showed that hypocotyl explants and 2,4-D (1 $\left.\mathrm{mg} \mathrm{l}^{-1}\right)$ attained about $50 \%$ of somatic embryos. In another study, hypocotyl explants of Eleutherococcus senticosus in MS medium produced $89 \%$ of somatic embryos (Han and Choi, 2003). Also, our results are the same with Aslam et al. (2004) on Catharanthus roseus (L.) G. Don, whom described that hypocotyl and 2,4-D (1 $\mathrm{m} \mathrm{gl}^{-1}$ ) were the combination of choice. Also, in another study on Catharanthus roseus (L.) G. Don; the most somatic embryos were observed using hypocotyl explants and $2 \mathrm{mgl}^{-1} 2,4-\mathrm{D}$. Auxins have synergistic effects with cytokinins and accelerate the cell division. 2,4-D may also add-up the endogenous levels of IAA in plant tissue, thereby creating dipoles within the cell and forming pre-embryonic structures (Mendez-Hernandez et al., 2019). 2,4-D promotes the accumulation of ROS (oxygen reactive species), and stimulates the ethylene and abscisic acid biosynthesis in plant tissue and ultimately induces stress behavior in plant tissue. As a result, plant cells change or shift to form somatic embryos (Bharatia et al., 2015; Wojcik et al., 2020). 2,4-D application and availability in the culture medium probably results in the expression of cell differentiation genes and the demethylation of DNA. 2,4-D plays an important role in the somatic embryos induction and in the stages of maturation and development of somatic embryos. Whereas, 2,4-D, has an inhibitory role with the biosynthesis of a number of proteins and mRNAs (Krishnan and Siril, 2017). In our study, calli from leaf explants were unable to produce somatic embryos (Gulzar et al., 2019). Otherwise, Paeonia ostii 'Feng Dan', Asparagus racemosus Willd, and Cnidium officinale Makino, the combinations of auxins and cytokinins produced reasonable somatic embryos (Adil et al., 2018; Chaudhary and Dantu, 2019; Ren et al., 2020).

Auxins had dominant effect on callus production of Catharanthus roseus (L.) G. Don. and the results showed that 2,4-D was much efficient than NAA. More somatic embryos were obtained from hypocotyl explants. Due to the medicinal importance of Catharanthus roseus, it is suggested that in the further studies, somatic embryogenesis behavior in this plant should be studied on a larger scale and that the possibility of somatic embryogenesis in a liquid culture medium using suspension culture should be tested in different ways. Therefore, it is possible to study the biosynthesis of secondary metabolites and valuable alkaloids in vitro conditions and to optimize the protocols to extract and purify the above mentioned metabolites.

\section{References}

ABATE M., MEKBIB F., GEBRE E., 2019 - In vitro somatic embryogenesis and plantlet regeneration in anchote [Coccinia abyssinica (Lam.) Cong.]. - Plant Physiol. Rep., 24: 351-358. 
ADHIKARI S.R., PANT B., 2013 - Induction and proliferation of in vitro mass of callus of Withania somnifera (L.) Dunal. - Res. Plant Sci., 1(3): 58-61.

ADIL M., KANG D.I., JEONG B.R., 2018 - Data on recurrent somatic embryogenesis and in vitro micropropagation of Conidium officinale Makino. - Dat. Brie., 19: 23112314.

ASLAM J., BHAT M., MUJIB A., SHARMA M.P., 2004 Somatic embryogenesis study in Catharanthus roseus (L.) G. Don: an anticancerous plant., XI: 98-106. - In: KHAN I.A., KHANUM A., (ed.) Role of biotechnology in medicinal and aromatic plants. Ukaaz Publication, Hyderabad.

ASLAM J., BHAT M.A., MUJIB A., SHARMA M.P., 2006 Somatic embryo proliferation, maturation and germination in Catharanthus roseus. - Plant Cell Tissue Organ Cult., 84: 325-332.

ASLAM J., MUJIB A., NASIM S.A., SHARMA M.P., 2009 Screening of vincristine yield in ex vitro somatic embryos derived plantlets of Catharanthus roseus $L$. (G) Don. - Scientia Hort., 119: 325-329.

ASLAM J., MUJIB A., SHARMA M.P., 2011 - Influence of freezing and non-freezing temperature on somatic embryogenesis and vinblastine production in Catharanthus roseus (L.) G. Don. - Ac. Physiol. Plant., 33(2): 473-480.

ASLAM J., MUJIB A., SHARMA M.P., SAMAJ J., 2007 Somatic embryogenesis and plant regeneration in Catharanthus roseus. - Biol. Plant., 51(4): 641-646.

BARRALES-CUREÑO H.J., ANDRADE-HOYOS P., LUNA-CRUZ A., REYES-REYES C., CHÁVEZ-SALINAS S., LÓPEZ-VALDEZ L.G., 2017 - In vitro biotechnological production and pharmacological studies of antileukemic alkaloids of Catharanthus roseus, pp. 17-34. - In: NAEEM M., AFTAB T., KHAN M.M.A., 2017 - Catharanthus roseus current research and prospects. Springer International Publishing, Springer, Cham. Switzerland, pp. 424.

BHARATIA S., SHARMA K., DAHIYA R., BERA T., 2015 Modern applications of plant biotechnology in pharmaceutical sciences. - Acad. Press, Elsevier, pp. 209-293.

BHOJWANI S.S., RAZDAN M.K., 1996 - Plant tissue culture: Theory and Practice. A revised edition. - Springer International Publishing, The Netherlands, pp. 125-130.

CHAUDHARY J., DANTU P.K., 2019 - Induction of somatic embryos in cultures of Asparagus racemosus Willd: an endangered medicinally important plant. - Bulletin of the National Research Centre, 43: 113.

CHOI Y.E., YANG D.C., YOON E.S., 1999 - Rapid propagation of Eleutherococcus senticosus via direct somatic embryogenesis from explants of seedling. - Plant Cell Tissue Organ Cult., 58(2): 93-97.

DEEPAK K.V., IVIN J.J.S., NARAYANA G.S., PRAKASH M., MURUGAN S., ANANDAN R., 2019 - Efficient plant regeneration and histological evaluations of regenerants through organogenesis and somatic embryogenesis in Spermacoce hispida L. An underutilized medicinal- ly important plant. - Ind. Crops Prod., 134: 292-302.

DHRUVA B., RAMAKRISHNAN T., VAIDYANTHAN C., 1977 Studies in Catharanthus roseus callus cultures, callus initiation and differentiation. - Curr. Sci., 46: 364-365.

FIROOZABABY E., DE BOER D.L., 1993 - Plant regeneration via somatic embryogenesis in many cultivars of cotton (Gossypium hirsutum L.). - In Vitro Cell Dev. Biol., 29: 166-173.

GEORGE E.F., HALL M.A., KLERK G.D., 2008 - Plant propagation by tissue culture. Volume 1. The Background. 3rd Edition. - Springer, The Netherlands, pp. 212-214.

GIRI A., AHUJA P.S., KUMAR P.V.A., 1993 - Somatic embryogenesis and plant regeneration from callus cultures of Aconitum heterophyllum Wall. - Plant Cell Tissue Organ Cult., 32: 213-218.

GOPI C., PONMURUGAN P., 2006 - Somatic embryogenesis and plant regeneration from leaf callus of Ocimum basilicum L. - J. Biotech., 126: 260-264.

GULZAR B., MUJIB A., RAJAM M., FRUKH A., ZAFAR N., 2019 - Identification of somatic embryogenesis (SE) related proteins through label-free shotgun proteomic method and cellular role in Catharanthus roseus (L.) G. Don. - Plant Cell Tissue Organ Cult., 137: 225-237.

HAN J.Y., CHOI Y.E., 2003 - Mass production of Eleutherococcus senticosus maxim. - Kor. J. Plant Biotech., 30(2): 167-172.

HOGAN S., 2003 - Flora: A gardener's encyclopedia. Timber Press Inc, Portland, Oregon, USA, 1: 343.

JI A., GENG X.U., ZHANG Y., YONG H., WU G.U., 2011 Advances in somatic embryogenesis research of horticultural plants. - Am. J. Plant Sci., 2: 727-732.

JIMENEZ V.M., THOMAS C., 2005 - Participation of plant hormones in determination and progression of somatic embryogenesis, pp. 103-106. - In: MUJIB A., and J. ŠAMAJ (eds.) Somatic embryogenesis. Plant cell monographs, Springer, Berlin, Heidelberg, Germany, pp. 357.

JUNAID A., MUJB A., BHAT M.A., ILAH A., SHARMA M.P., 2006 - Embryogenesis in Catharanthus roseus: Roles of some external factors in proliferation, maturation and germination of embryos, pp. 259-270. - In: MUJIB A., and J. ŠAMAJ (eds.) Somatic embryogenesis. Plant cell monographs, Springer, Berlin, Heidelberg, Germany, pp. 357.

JUSHEE N., BISWAS B.K., YADAK A.K., 2007 - Somatic embryogenesis and plant development in Centella asiatica L., a highly prized medicinal plant of the tropics. Hort. Sci., 42(3): 633-637.

KIM S.W., JUNG K., SONG N., KWAK S., LIU J., 1994 - High frequency plant regeneration from anther-derived cell suspension cultures via somatic embryogenesis in Catharanthus roseus. - Plant Cell Rep., 13: 319.

KRISHNAN S.R.S., SIRIL E.A., 2017 - Auxin and nutritional stress coupled somatic embryogenesis in Oldenlandia umbellata L. - Physiol. Mol. Biol. Plants., 23(2): 471475.

MARTIN K.P., 2003 - Plant regeneration through somatic 
embryogenesis on Holostemma adakodien. - Plant Cell Tissue Organ Cult., 72: 79-82.

MARTIN K.P., 2004 - Plant regeneration through embryogenesis in medicinally important Centella asiatica L.- In Vitro Cell \& Devel. Biol. - Plant., 40: 586-591.

MENDEZ-HERNANDEZ A.H., LEDEZMA-RODRIGUEZ M., AVILEZ-MONTALO R.N., JUAREZ-GOMEZ Y.L., SKEETE A., AVILEZ-MONTALVO J., DE-LA-PENA C., LOYOLA-VARGAS V.M., 2019 - Signal overview of plant somatic embryogenesis. - Front. Plant Sci., 10: 77.

MIKULA A., RYBCZYNSKI J., 2001 - Somatic embryogenesis of Gentiana genus I. the effect of the preculture treatment and primary explants origin on somatic embryogenesis of Gentiana cruciata (L.), G. pannonica (scop.) and G. tibetica (king). - Act. Physiol. Plant., 23(1): 1525.

MUJIB A., ILAH A., ASLAM J., FATIMA S., SIDDIQUI Z.H., MAQSOOD M., 2012 - Catharanthus roseus alkaloids: application of biotechnology for improving yield. - Plant Grow. Reg., 68: 111-127.

MURASHIGE T., SKOOG F., 1962 - A revised medium for rapid growth and bioassays with tobacco tissue cultures. - Physiol. Plant., 15: 473-497.

PARAMAGEETHAM C.H., BABU G.P., RAO J.V.S., 2004 Somatic embryogenesis in Centella asiatica $L$. an medicinal and neutraceutical plant of India. - Plant Cell Tissue Organ Cult., 79: 19-24.

RAMAWAT K.G., RAJBHANSALI R., ARYA H.C., 1987 - Shoot formation in Catharanthus roseus (L.) G. Don callus cultures. - Curr. Sci., 77: 93-94.

REN X., LIU Y., JEONG B.R., 2020 - Enhanced somatic embryo induction of a tree peony, Paeonia ostii 'Fengdan', by a combination of 6-benzylaminopurine (BA) and 1-naphthylacetic acid (NAA). - Plants, 9: 3.

SINGH R., KHARB P., RANI K., 2011 - Rapid micropropagation and callus induction of Catharanthus roseus in vitro different explants. - World J. Agr. Sci., 7(6): 699704.

TANIDA K., SHIOTA H., 2019 - Anise-cultured cells abolish 2,4-dichlorophenoxyacetic acid in culture medium. Plant Biotech., 36: 209-212.

VAN DER HEIJDEN R., JACOBS D.T., SNOEIJER W., HALLARD D., VERPOORTE R., 2004 - The Catharanthus alkaloids: pharmacognosy and biochemistry. - Curr. Med. Chem., 11: 607-628.

VON ARNOLD S., SABALA I., BOZHKOV P., DYACHOK J., FILONOVA L., 2002 - Developmental pathway of somatic embryogenesis. - Plant Cell Tissue Organ Cult., 69: 233-249.

WOJCIK A.M., WOJCIKOWSKA B., GAJ M.D., 2020 - Current perspectives on the auxin-mediated genetic network that controls the induction of somatic embryogenesis in plants. - Int. J. Mol. Sci., 21: 1333.

WOJCIKOWSKA B., GAJ M.D., 2016 - Somatic embryogenesis: Fundamental aspects and applications. - Springer International Publishing Switzerland, pp. 185-199. 
